\title{
cculturation or autonomy? Controversy over the status of the Sámi in Finland during the interwar period
}

\section{Kari Alenius}

University of Oulu, E-mail: kari.alenius@oulu.fi

https://orcid.org/0000-0002-0339-2922

\section{Abstract}

The newly independent Finland in the 1920s and 1930s was, in principle, a nation state in which ethnic Finns had an undisputed leading position. Nevertheless, there was a lively debate about the status that would be given to other nationalities in various spheres of social life. The Swedes were the country's main national minority (accounting for 10 per cent of the total population), and they were granted extensive minority rights. Another locally significant minority were the Sámi who lived in northern Lapland. This paper analyses the extent to which the majority population was willing to meet the wishes of the Sámi. Some Finns were in favour of the Sámi being acculturated as quickly as possible, but a few activists would have liked to grant the Sámi broad autonomy. Several ministries and government agencies investigated the matter thoroughly, but the result was negative for the Sámi.

\section{Rezumat}

Finlanda anilor '20 și '30, recent independentă, a fost, în principiu, un stat național în care etnicii finlandezi dețineau poziția de lider de necontestat. $\mathrm{Cu}$ toate acestea, a existat o dezbatere aprinsă $\mathrm{cu}$ privire la statutul care urma a fi acordat altor naționalități $\hat{i}$ diverse sfere ale vieții sociale. Suedezii constituiau principala minoritate națională a țării (reprezentând $10 \%$ din populația totală) și acestora li s-au acordat drepturi minoritare extinse. O altă minoritate semnificativă la nivel local a fost sami, care locuiau în nordul Laponiei. Această lucrare analizează măsura în care populația majoritară a fost dispusă să indeplinească doleanțele populației sami. Unii finlandezi au fost în favoarea ideii ca sami să fie asimilați cât mai repede posibil, dar câțiva activiști ar fi dorit să acorde acestei populații o autonomie largă. Mai multe ministere și agenții guvernamentale au investigat problema în detaliu, dar rezultatul a fost în final negativ pentru sami.

Keywords: Ethnic relations; multiculturalism; Finland; Sámi; self-government

CC BY-SA License (https://creativecommons.org/licenses/by-sa/2.0)

This paper has been presented at the Twelve International Conference on Baltic and Nordic Studies in Romania: ReThinking multiculturalism, multilingualism and cultural diplomacy in Scandinavia and the Baltic Sea Region, hosted by the Romanian Association for Baltic and Nordic Studies, May 27-28, 2021. 


\section{Introduction}

Today, issues related to multiculturalism are topical throughout Europe and North America. However, this is not a new thing, although the term 'multiculturalism' is quite recent. There is not just one generally accepted definition for it. In any case, this article applies a general delineation in the study of history and sociology which focuses only on the analysis of relations between groups of people without taking a position on future policy goals. The delimitation of the perspective is summarised in the Encyclopaedia Britannica, for instance, as follows:

'Multiculturalism; the view that cultures, races, and ethnicities, particularly those of minority groups, deserve special acknowledgment of their differences within a dominant political culture. That acknowledgment can take the forms of recognition of contributions to the cultural life of the political community as a whole, a demand for special protection under the law for certain cultural groups, or autonomous rights of governance for certain cultures [...] Multiculturalism seeks the inclusion of the views and contributions of diverse members of society while maintaining respect for their differences and withholding the demand for their assimilation into the dominant culture. ${ }^{1}$

Finland became independent in 1917, after which a new constitution was created. In this context, a position had to be taken, inter alia, on the situation of ethnic minorities. In 1920, Finland had a population of 3.15 million, of whom about 88 per cent were ethnic Finns and 11 per cent Swedes (or Swedish speakers, which was and still is the official term). The combined share of all other minorities was less than one per cent. The number of Sámi was just over 2,000, but in Lapland - the northernmost part of Finland - they were a locally significant minority. The three northernmost municipalities in Finland proper - Enontekiö, Inari and Utsjoki - had a total of about 4,000 inhabitants, half of whom were Sámi and half Finns. In addition, in the 1920

\footnotetext{
1 Jennifer L. Eagan, "Multiculturalism", in Encyclopedia Britannica, https://www.britannica.com/topic/multiculturalism (7.7.2021).
} 
peace treaty, Finland gained the Petsamo area, of which about 20 per cent (400) of the inhabitants (2000) were Sámi. These municipalities were large in area but very sparsely populated. Their infrastructure was weak, and connections to the rest of Finland were relatively limited. ${ }^{2}$

At the national level, the Swedes were the only significant minority, and they were the only minority group to be granted extensive autonomous rights in the Constitution. Other minorities were not mentioned in the legislation as groups, but members of small minorities were subject only to the general human rights defined for all citizens. It can be said that between the World Wars, Finland pursued a kind of multicultural policy in relation to the Swedish minority, although the term 'multiculturalism' was not yet used at that time. However, the debate on the rights and responsibilities of 'national minorities' was quite similar to the debate on multiculturalism in the 21st century.

This paper analyses the extent to which the majority population was willing to meet the wishes of the Sámi. Some Finns were in favour of the Sámi being acculturated as quickly as possible, but a few activists would have liked to grant the Sámi broad autonomy. What arguments were made for and against the 'multiculturalism' of the Lapland region? What kinds of solutions were finally reached and why?

The article consists of three parts. First, it analyses the types of selfgovernment that were considered for the Sámi. This perspective is most important because if autonomy had been realised, it would have had a comprehensive impact on all walks of life. The analysis is supplemented by reviews of Sámi school life and the organisation of ecclesiastical affairs. Multiculturalism, especially from the point of view of the use of the Sámi language, was also present in these latter areas.

The study is based on the analysis of archival material and the contemporary press. The topic has been explored to some extent in the past, but there is still room for in-depth analysis. Of the previous researchers, VeliPekka Lehtola has done the most thorough work. His main work is Saamelaiset suomalaiset - kohtaamisia 1896-1953 (Sámi Finns - Encounters

\footnotetext{
2 Suomen Tilastollinen Vuosikirja 1922 (Helsinki, 1922), pp. 10-36; Suomen Tilastollinen Vuosikirja 1932 (Helsinki 1932), 12-45; Suomen Tilastollinen Vuosikirja 1942 (Helsinki 1943), 14-47.
} 
1896-1953)3 ${ }^{3}$, in which he has also partly utilised the same materials. In this article, however, I focus more on the goals, aspirations, and fears of the various actors that explain why certain types of solutions were ultimately decided upon.

\section{The Utsjoki case in 1925: Local Sámi autonomy quickly rejected}

Other minorities than the Swedes did not have their own parties between the World Wars, but that did not mean that they did not take a stand or try to influence their own position in Finnish society. In the history of small minorities in the 1920s and 1930s, there are a few examples which parallel what happened in the life of the Swedish-speaking minority. The Sámi were the group whose position, in principle, most closely resembled that of the Swedes. The Sámi lived in the northern border region (like the Swedes in the west), and on the other side of the state border lived people belonging to the same group. As it was an ethnic, linguistic and cultural minority whose area of residence could be defined quite precisely, like the Swedish-speaking people, even the idea of a kind of cultural autonomy came up.

In 1920, the northernmost municipality in Finland, Utsjoki, had about 550 inhabitants, of whom 490, or quite accurately 90 per cent, were Sámi. As a result of migration and high birth rates, by 1930, the municipality's population had grown to 680, of whom 610 were Sámi. Thus, the Sámi population had generally remained the same, although in all other municipalities in the Sámi region, the Finns increased in number at the same time. The situation was affected by the special features of Utsjoki. It was remote, and there was not even a road there. Utsjoki also had no business that would have attracted Finnish migrants. Its main traffic route was the Teno River, which empties into the Arctic Ocean and is the border between Finland and Norway. Utsjoki's connections to the south, to the rest of Finland, were traditionally limited. In contrast, to the north towards Norway, the connections were considerably busier. ${ }^{4}$

\footnotetext{
${ }^{3}$ Veli-Pekka Lehtola, Saamelaiset suomalaiset - kohtaamisia 1896-1953 (Helsinki: SKS, 2012).

${ }^{4}$ Lehtola 2012, 26, 214-218.
} 




The general goal of the Finnish state was to ensure that it had sufficient control in all parts of the country. This was particularly the case in border regions which were important for national security and which were of interest to another state. The way to ensure adequate control was to integrate the border regions as comprehensively as possible into the rest of the country. At the same time, an essential element was to raise all residents to be loyal citizens of the Finnish nation-state. If strong social integration was

${ }^{5}$ Source: Wikimedia Commons (background); with substantial changes by the author (KA). 
not desired at the local level and Finnish national values were not shared, it inevitably caused a clash. Utsjoki was in this situation in the mid-1920s.

In February 1925, Aukusti Neitiniemi, Member of Parliament for the Coalition Party, submitted a proposal to Parliament based on a draft prepared by the Utsjoki Municipal Council at its own meeting. Neitiniemi was ethnically Finnish, but he was from the border of the Sámi region, Kittilä, and it seems that he was very sympathetic to the wishes of the Sámi. There were no Sámi MPs in the Finnish Parliament, so they had to ask someone to act as a mediator. Neitiniemi's proposal to Parliament had two main points. First, the Utsjoki Sámi municipal council proposed that Utsjoki be "preserved as an actual Sámi area". Secondly, the concrete way of achieving this was that without the consent of the Utsjoki Municipal Council, only Finns acting as state officials would be allowed to move to the municipality. ${ }^{6}$

The proposal recalled the arrangements established in the Aland Autonomy Laws. Those who came from other parts of Finland did not automatically have the right to remain living in Åland, and although the law did not explicitly state this, Alland was also guaranteed the right to "remain an actual Swedish territory" in practice. The ideas of the Sámi leadership of Utsjoki were received by the Finns in three ways. A few Finnish public figures warmly supported the idea, a few others opposed the idea just as strongly, and some fell between the two extremes. The discussion took place mainly in the newspaper sections of Northern Finland and in Parliament's Economic Committee.

Supporters relied on two arguments. According to them, farther south, Inari had already seen what difficulties the municipalities of the Sámi area faced when "adventurers and criminals" moved from elsewhere in Finland. Any kind of "bad life" and unrest had since increased. In addition, migrants had remained a burden on the poor relief in municipalities. Secondly, supporters argued that farming in the Sámi area was difficult due

\footnotetext{
${ }^{6}$ A. Neitiniemi, Yhtenäisen suunnitelman valmistamisesta valtakunnan lapinkielisen väestön taloudellisen ja sivistyksellisen tilan kohottamista varten (18.2.1925). Valtiopäiväasiakirjat (1925), Liitteet IV,2, 295-296; “Huomattawa esitys lappalaisasutuksen turwaamiseksi PohjoisLapissa". Rovaniemi 7.2.1925.
} 
to the rugged soil and cold climate. It was useless for Finnish settlers to move north because they would not be able to get along there. ${ }^{7}$

In the practical reasoning mentioned above, the issue was not directly linked to ethnic considerations, although it was clearly underlying. However, a few people brought just that to the centre and broadened the perspective to cover the entire Sámi area. In addition to MP Neitiniemi, the Finnish colonel and war historian Eero Heickell (Kuussaari) raised the matter most clearly in public. He had taken part in wars around Finland to liberate Finns or peoples ethnically close to them from Russia and Bolshevism, and he actively worked to promote the national and cultural well-being of these peoples. ${ }^{8}$ Heickell clearly also felt the same about the Sámi according to the same principle: for him, the Sámi were a kindred people of the Finns, and the Finns had to help preserve their national characteristics.

In March 1925, Heickell wrote an article for one of Northern Finland's leading newspapers, in which he presented his ideas. He demanded that the northernmost part of Finland, roughly the current Sámi homeland, be separated into a kind of "protected area" where Finnish settlers could not settle. The final statement of Heickell's article was "Let the Lapps be given their own land!"9 Heickell did not define the legal status of "Lappish land", but in practice, it would have been a matter of national autonomy, as in the case of Åland. Heickell was the greatest representative of Finns who were concerned about the preservation of the Sámi language and culture and who were ready to restrict the rights of Finns and the Finnish state in the traditional Sámi area.

In contrast, the Finnish police chief in Utsjoki, Eero Manninen, was the clearest representative of the other party in the public eye. A few weeks later, he wrote an article in the same newspaper in which he completely rejected Heickell's proposal. Manninen considered the Sámi to be cunning and calculating Norwegian admirers who despised the Finns. According to

\footnotetext{
${ }^{7}$ Lehtola 2012, 26, 219-221.

8 Mikko Uola, "Kuussaari, Eero". Kansallisbiografia-verkkojulkaisu. Studia Biographica 4. https://kansallisbiografia.fi/kansallisbiografia/henkilo/7749 (29.12.2020).

${ }_{9}$ A. Heickell “Lappalaisemme kansallisesti turwattawa”. Rovaniemi 3.3.1925.
} 
Manninen, the goal of the Sámi was to isolate or even to separate Utsjoki from Finland and connect it to Norway. Such separatism had to be prevented and, on the contrary, the integration of Utsjoki into Finland was enhanced. Manninen also claimed that the Sámi themselves were not interested in preserving their own language and culture but were willing to merge with the Norwegians. Therefore, there was no need for any kind of Sámi autonomy; rather, these ideas were directly harmful or downright treacherous to Finland. ${ }^{10}$

The views of those who were critical were confirmed by the fact that in May 1925, the Utsjoki Municipal Council decided on new measures that seemed separatist. The Council addressed the governor of Oulu County, proposing that no road or telephone connections be built to Utsjoki that would connect the municipality to the rest of Finland; it also recommended that a Finnish Border Guard station not be established in Utsjoki. A month later, the Inari Municipal Council - clearly encouraged by the example of Utsjoki - also proposed an amendment to the Finnish Migration Act, which could prevent unwanted immigrants from settling in the municipality. Inari only referred to economic and social factors, i.e. the fact that in previous years, a large amount of "harmful substances" had moved to the municipality from Southern Finland. ${ }^{11}$ However, in the background, there were probably the same, broader motives as in Utsjoki.

In June 1926, the chairman of the Utsjoki Municipal Council, O. J. Guttorm, revealed these motives in more detail in his article for the Rovaniemi newspaper. First, Guttorm reiterated the claims and arguments made earlier. In addition, he stated quite openly that the Finnish Border Guard was not wanted in Utsjoki because, in possible times of crisis, it would be important that the border with Norway remain open. At the end of World War I, great difficulties had been experienced when Russian measures prevented cross-border trade, even though Utsjoki suffered from food

\footnotetext{
${ }^{10}$ E.N.M. [Eero Manninen]. “Lappalaisalueen muodostamisesta”. Rovaniemi 2.4.1925.

${ }^{11}$ Terho Itkonen, "Lapin suojeleminen - Suomen suojelemista”. Rovaniemi 12.3.1925; "Utsjoen eristäytymispyrkimykset". Rovaniemi 11.5.1926. See also Lehtola 2012, 220-224.
} 
shortages. Guttorm also summarised the view of the local Sámi elite that "Utsjoki residents would like to develop alongside Finns as Sámi". ${ }^{12}$

What seemed natural from the point of view of Guttorm and perhaps many other locals did not receive much understanding from the Finns. In practice, the Municipal Council suggested that the Finnish border authorities would not have competence in the Utsjoki area. Keeping "unwanted elements" outside the municipality, preventing free movement, building roads and establishing telephone connections also proved to be a radical attempt at isolation. It is likely that the rise of the Sámi as full-fledged actors alongside the Finns also provoked a backlash. When the Sámi were traditionally seen as primitive and inferior among Finns, it was undoubtedly difficult for many to accept the idea of equality. The reaction is evidenced, for instance, by the fact that Rovaniemi magazine, which had previously taken a positive view of the Utsjoki Municipal Council's proposals, ${ }^{13}$ now changed its position and criticised Guttorm's views. ${ }^{14}$

In any case, the initiative taken by the Member of Parliament Neitiniemi was discussed in the Parliament's Committee on Education and the Committee on Economic Affairs in the autumn of 1925. Both committees reacted negatively to the proposal. They reasoned that the municipality of Utsjoki should not be treated as a special case, but things had to be organised there as in other border regions of Finland. The Committee on Economic Affairs also did not consider it necessary to establish a separate "Lappish area protected from other settlements" because the natural conditions of Utsjoki were unsuitable for Finnish farmers anyway. When the position of both committees was negative, Neitiniemi's proposal was rejected in Parliament without debate. No member of Parliament considered it necessary to comment on or defend the views of the Sámi. ${ }^{15}$

12 O.J.G. [O. J. Guttorm]. “'Utsjoen eristäytymispyrkimykset' y.m. kirjoitusten johdosta”. Rovaniemi 19.6.1926.

13 "Huomattawa esitys lappalaisasutuksen turwaamiseksi Pohjois-Lapissa". Rovaniemi 7.2.1925.

14 Toimitus. Rovaniemi 19.6.1926.

${ }^{15}$ Anomusmietintö N:o 17, Talousvaliokunnan mietintö lapinkielisen väestön taloudellisen ja sivistyksellisen tilan kohottamista koskevan anomusehdotuksen johdosta 25.11.1925. Asiakirjat II V. Valtiopäiväasiakirjat 1925; “Lapinkielisen wäestön taloudellisen ja siwistyksellisen tilan kohottaminen". Rovaniemi 18.2.1926. 
However, giving some autonomy to the Sámi or to some of them came up again in the early 1930s. This time, it was about the Skolt Sámi in the Petsamo area, and the proposal that arose from among them was more positively received by the Finns. There were several reasons behind the fact that attitudes were different.

\section{The Skolt Sámi case in 1930-1938: A reservation for 'Finnish Indians' under serious consideration}

As a result of the Tartu Peace Treaty in 1920, Finland acquired the Petsamo area and a new ethnic group at the same time, the Skolt Sámi, whose residential area covers the western part of the Kola Peninsula. Petsamo was formed into a municipality with an area of about 10,500 square kilometres. In the early 1920s, however, there were only about 2,000 inhabitants, so the area was very sparsely populated. Fewer than 400 of the inhabitants were Skolt Sámi, and they lived mainly in the southern part of Petsamo. The largest group of the multi-ethnic population, about 600 people, were Finns, and Karelians, other Sámi and Russians also lived in the area. The settlement was concentrated in the northern parts of Petsamo, especially along the shores of the Arctic Ocean. Between the World Wars, Petsamo was subject to strong Finnish migration. In 1939, Petsamo had a population of about 5,100, of which nearly 4,000 were ethnically Finnish. ${ }^{16}$

The main occupation of the Skolt Sámi was reindeer herding, and their way of life was nomadic. The Suonikylä (Suenjel) region, located in the forest area in the southern part of Petsamo, was the core area of Skolt Sámi culture in the sense that most of the Skolt lived there, and there were few Finns or other inhabitants in that area. The winter village of Suenjel and some of the reindeer pastures became part of the Soviet Union according to the peace treaty, but the inhabitants of Suenjel were allowed to build a new winter village in the 1920s with Finnish state funds. The rapid change in society in the 1920s raised similar concerns among the Skolt population as with the Sámi in the Utsjoki and Inari areas. In the western and northern parts of Petsamo, the traditional Skolt communities were facing great

${ }^{16}$ Suomen Tilastollinen Vuosikirja 1932, pp. 36-45; Suomen Tilastollinen Vuosikirja 1942, 40-48. See also Lehtola 2012, 24, 255-256. 
difficulty, but the changes had little effect on the Suenjel area. However, there were also emerging threats in Suenjel from the perspective of the Skolt Sámi. Finnish professional fishermen had come to compete for the fishing waters that the Skolt population had considered their own property for generations. In addition, there were conflicts of interest between Finnish and Skolt Sámi reindeer herders. After the Skolt Sámi had to give up some of the pastures in the peace treaty, they had to find new ones in the Petsamo area, which caused controversy. There were no completely unused new pastures available, and a rising number of reindeer herders and reindeer were forced to share shrinking pastures. ${ }^{17}$

In December 1930, the inhabitants of Suenjel held a village meeting, in which they decided to turn to the Finnish government and ask for protection. Imperial Russia had granted certain special trade privileges, which the Skolt wanted to preserve. However, it was not just about reindeer husbandry, hunting and fishing. The Skolt of Suenjel wanted the Finnish government to ensure the continuation of the "self-sufficient, nature-based life of the Skolt people" without disruption. ${ }^{18}$

Supported by a few Finnish officials in Petsamo, the matter progressed to the Ministry of the Interior, which in 1932 made an official initiative to exclude Suenjel from the scope of the Petsamo Settlement Act. The Ministry of the Interior was of the opinion that a separate Skolt territory should be formed in the southern part of Petsamo so that "the ethnologically very interesting Skolt population could continue in peace their natural life as before and thus survive extinction". However, the matter still required a round of consultations asking for the views of other authorities. Petsamo belonged to the province of Oulu, the governor of which took a positive stance, as did the Ministry of Agriculture. ${ }^{19}$

In the summer of 1933, a study was carried out with the aim of finding an agreement between the Skolt and the Finns in the Petsamo area

\footnotetext{
17 Lehtola 2012, 257-261, 267-270.

18 Suonikylän uuden talvikylän kolttain kokous 12.12.1930. Petsamon kihlakunnan kruununvoudin arkisto [hereafter PKKA] BI:45.

${ }^{19}$ Sisäasiainministeriö Petsamon kihlakunnan kruununvoudille 19.6.1931. PKKA BI:45; L. Itkonen, "Suonikylän territoriokysymys (I)". Lapin Kansa 2.7.1936; L. Itkonen, "Suonikylän territoriokysymys (II)". Lapin Kansa 4.7.1936.
} 
about which part of Petsamo could be separated into a "Skolt territory". In particular, there was disagreement over hunting and fishing rights and how other natural resources in the region would be used. In any case, based on the study, a proposal was made that the area would be approximately 4,200 square kilometres, or more than 40 per cent of the area of the municipality of Petsamo. Admittedly, there were only about 200 inhabitants, all of them Skolt Sámi. The following year, the National Board of Settlements and the National Land Survey of Finland supported the plan. In addition to defining the boundaries of the area, professional fishing and hunting for non-Skolt peoples would be prohibited, and Finnish settlers would not be allowed to move into the territory. ${ }^{20}$

However, progress stalled, although the proposal was welcomed by some ministries and central government departments. The strongest opposition to the project came from Petsamo's local level. The Petsamo Municipal Council, which consisted mainly of Finns who had just moved to the area, strongly opposed the establishment of a special territory. In its opinion, the project would have been against the interests of other Petsamo residents, and it was also expected to cause administrative problems and financial costs. The National Board of Forestry also came to a negative conclusion. In its opinion, increasing the interaction between the Skolt and the Finns and integrating the Skolt into the rest of society was only a positive development. The National Board of Forestry also did not accept the restrictions on the utilisation of natural resources around the special territory, for instance logging or the establishment of possible mines. ${ }^{21}$

A number of Finns who were sympathetic towards the Skolt and the Sámi in general still tried to take the project forward by actively influencing people's opinions. These "Lappofiles" had founded an association in 1932 called the Lapland Educational Society, whose main purpose was to support

\footnotetext{
${ }^{20}$ Sisäasiainministeriö Maatalousministeriölle 3.10.1932. PKKA BI:45; L. Itkonen," Suonikylän territoriokysymys (II)". Lapin Kansa 4.7.1936; L. Itkonen, "Suonikylän territoriokysymys (III)". Lapin Kansa 7.7.1936.

${ }^{21}$ Petsamon kunnanvaltuuston kokous 30.3.1931. Petsamon kunnan arkisto Ca:1-3; L. Itkonen, "Suonikylän territoriokysymys (I)". Lapin Kansa 2.7.1936; L. Itkonen, "Suonikylän territoriokysymys (II)". Lapin Kansa 4.7.1936; L. Itkonen, "Suonikylän territoriokysymys (III)". Lapin Kansa 7.7.1936.
} 
Sámi culture. In 1936-1937, the Lapland Educational Society contacted several domestic and foreign scientific associations and influential politicians and officials and asked them for statements, which were used to support the plan for the special territory. Such bodies included, among others, the U.S. Commissioner of Indian Affairs and some indigenous (Native American) organisations. ${ }^{22}$

The project to establish a Skolt Sámi Special Territory was conceptually very close to what was done in North America in the establishment and management of Indian reservations. In 1934, a new Indian Law had come into force in the United States; its main purpose was to keep Native American settlements in the possession of Native Americans. So, fresh examples were available from there. In the spring of 1937, K. Nickul, a member of the Lapland Educational Society, wrote an extensive article in Finland's largest magazine, Suomen Kuvalehti, entitled "How are the 'Indians' in Finland?" Nickul thus openly equated the Skolt with Native Americans, and the Lapland Educational Society extended its goals to cover all Finnish Sámi. The aim was therefore to establish Sámi "reservations", the first of which should be created for the Petsamo Skolt Sámi. ${ }^{23}$

It should come as no surprise that the campaigning of the Lapland Educational Society also provoked reactions from members of the public, who opposed the granting of any special rights to the Sámi. In the late 1930s, the government continued to compile various reports, even though the matter had been pending for nearly a decade. A special Lapland Committee set up for this purpose issued a negative final report in the autumn of 1937. The top management of the new Lapland County, founded in 1938, reached the same conclusion. ${ }^{24}$ The end point came with World War II. It was clear in principle that during the war (1939-1945), it was not possible to implement

\footnotetext{
22 "Lappalaisen kulttuurin suojelualueen muodostamisen puolesta puhuvat monet painavat näkökohdat”. Rovaniemi 3.3.1936; Karl Nickul, "Suonikylän lappalaiskulttuurin vaaliminen”. Helsingin Sanomat 1.11.1937. See also Lehtola 2012, 338-339.

${ }^{23}$ Karl Nickul, “Miten käy Suomen 'intiaanien'?” Suomen Kuvalehti 17/1937.

${ }^{24}$ Lapin läänin maaherra Maatalousministeriölle 11.5.1938. Kaarlo Hillilän arkisto D:7; "Maamme väkiluku on niin pieni, ettei sillä ole varaa perustaa 'kansatieteellisiä ihmistarhoja'". Rovaniemi 3.5.1938.
} 
any reforms such as the "Sámi reservations". As a result of the war, Finland also lost the Petsamo area.

In practice, the project had been rejected anyway by both the local Finns and the Finnish government by 1938 at the latest. The decisive factor seems to have been that the government did not want to act against the will strongly expressed by the Finnish residents of the Petsamo area. The government also hesitated to grant autonomy or other special rights to the residents of the northern border areas, whose loyalty to Finland was uncertain. There were also very few Sámi, and therefore, they had little opportunity to put pressure on those in power - and the first Sámi national organisation, the Sámi Union, was not founded until 1945. Creating special arrangements for a few hundred people seemed disproportionately cumbersome and expensive. Ultimately, it was undoubtedly also the case that recognising the Sámi as an equal nation, whose culture and identity should have been supported, was against Finnish nationalist ideals. The general goal was to strengthen Finnishness and reduce all kinds of internal differences in the Finnish nation-state.

\section{Finnish-language school for the Sámi}

Between the World Wars, the level of education of the Sámi was clearly lower than the average for the Finnish population. The situation was influenced by several cultural and social factors. One factor was the predominantly nomadic or semi-nomadic lifestyle of the Sámi, which was tied to reindeer husbandry. Schooling was difficult because the place of residence could change according to the annual cycle. Reindeer husbandry also did not require a formal education, but the necessary skills were acquired by working with the rest of the family from childhood. When the construction of schools and the provision of general education for all were discussed in the Sámi area in the 1920s and 1930s, several Sámi expressed the view that they did not find any need for schooling. ${ }^{25}$

\footnotetext{
${ }^{25}$ Lehtola 2012, p. 281; Jukka Nyyssönen, "Saamelaisten kouluolot 1900-luvulla”, in Pigga Keskitalo, Veli-Pekka Lehtola, Merja Paksuniemi (eds.), Saamelaisten kansanopetuksen ja koulunkäynnin historia Suomessa (Turku: Siirtolaisuusinstituutti, 2014), 66.
} 
Another factor relating to the Sámi's low level of education was that the Sámi lived in remote areas of Northern Finland, where transport connections were weak and the school network was sparse. In Finland, a law on general compulsory education was passed in 1921. However, it only applied to children who lived no more than five kilometres from the school. In the Sámi settlement area, the population density was remarkably low, and the distances from one village to another were long. ${ }^{26}$ In addition, the abovementioned mobile lifestyle made applying the law quite open to interpretation: if, for instance, a summer village was less than five kilometres from school but a winter village was farther away, were children subject to compulsory education?

For the Sámi, education was organised until the end of the 1940s, mainly as rotating schools. In practice, this meant that itinerant teachers (catechists) moved from place to place and taught children in sparsely populated remote areas for a short time before moving on to a new place. Teaching periods lasted a few weeks or months, followed by a long pause. Learning outcomes were understandably lower in rotating schools than in regularly operating schools with a normal semester rhythm. The rotating school system covered all residents of sparsely populated areas, regardless of ethnic background, like many Finnish children in small villages in Northern Finland. ${ }^{27}$

In the 1920s and 1930s, more schools were established in all municipalities in the Sámi region. The Compulsory Education Act of 1921 required the construction of a "sufficient number" of schools in all Finnish municipalities so that all children could attend school in the normal way. As the construction of schools was a major financial burden for the sparsely populated and poor municipalities in the outermost regions, the law set a transition period of 16 years. Thus, it was the duty of the municipalities to create a comprehensive school network by 1937.28 It was possible for municipalities to apply for state support for the construction of schools, and municipalities in the Sámi area also took advantage of this opportunity. At

\footnotetext{
${ }^{26}$ Laki oppivelvollisuudesta. Suomen Asetuskokoelma N:o 101/1921.

${ }^{27}$ Lehtola 2012, pp. 281-283; Nyyssönen 2014, 65.

${ }^{28}$ Laki oppivelvollisuudesta. Suomen Asetuskokoelma N:o 101/1921.
} 
the end of the transition period, however, it became clear that, despite significant progress, the school network was still not completely seamless. The last rotating teachers did not stop working until the 1950s. ${ }^{29}$

The third background factor related to the Sámi's low level of education was that they had to attend their school in a foreign language, Finnish. In fact, the situation in this regard deteriorated between the World Wars. Even before Finland's independence, most of the teachers in the Sámi region were proficient in the Sámi language, and for them, the situation remained more or less the same. Although teaching was still largely in Finnish, Sámi could be used as an auxiliary language. Since most Sámi children who started school were completely unfamiliar with the Finnish language, learning was naturally promoted if the teacher was able to use Sámi in addition to Finnish. Rotating teachers who taught in the Sámi area were therefore required to have at least the ability to understand the Sámi language. ${ }^{30}$

The situation was exacerbated, above all, by the fact that using Sámi as an auxiliary language was less frequent in the actual schools than in the traditional rotating schools. In the actual schools, the spirit of the time seems to have prevailed, according to which Finland was to become a unified Finnish national state. From that perspective, it was not desirable that schoolchildren such as the Sámi, who belonged to small and "undeveloped" ethnic groups, would receive schooling in their own language. Finnish nationalists were also concerned that it was not possible to control teaching in other languages as closely as in Finnish. In Utsjoki, for instance, there were speculations that the Sámi might be raised in an anti-Finnish spirit and encouraged to isolate themselves from the rest of Finland or even to sympathise with Norway, which had expansive goals in the north. ${ }^{31}$

On the other hand, the lack of Sámi-language schooling was not just a project of nationalist Finns. When the Sámi themselves took a stand on the matter, they almost always wanted their children to attend school in Finnish.

\footnotetext{
${ }^{29}$ Nyyssönen 2014, p. 64.

30 Terho Itkonen, “Lappalaisuuden ei ole tarvis sortua”. Rovaniemi 11.5.1929. See also Lehtola 2012, 281-284.

${ }^{31}$ E.N.M. [Eero Manninen]. “Lappalaisalueen muodostamisesta”. Rovaniemi 2.4.1925. See also Lehtola 2012, 283, 288-289.
} 
They did not see the Finnish-language school as a linguistic or cultural threat because "everyone, of course, learns the Sámi language at home". The parents of the schoolchildren looked at the matter from a purely practical point of view. If schooling was required, it was good that the children learned the official language as fully as possible. Excellent Finnish skills then opened up equal opportunities for better jobs, influential positions and social advancement in general. ${ }^{32}$

\section{The Sámi languages alongside the Finnish language in the teaching of religion}

The majority of Sámi (about 80\%) belonged to the Evangelical Lutheran Church. The exceptions were the Skolt Sámi of the Petsamo area, whose traditional residential area was first connected to Finland in 1920. Before that, they had been subject to the Russian state and had adopted its Orthodox faith. The Evangelical Lutheran Church of Finland did not have fully Sámi-speaking congregations between the World Wars, but in the northernmost municipalities of Finland where many of the parishioners were Sámi, the Sámi language was widely used in all ecclesiastical ordinances. The Bible was translated into Northern Sámi in Norway in 1895 and was also used in Finland. In the vicinity of Lake Inarinjärvi, however, Inari Sámi was spoken, which differed from Northern Sámi so much that the speakers did not understand each other. Literature published in Northern Sámi could not be used for the same reason. The same was true of the Skolt Sámi, who had little native Christian literature. ${ }^{33}$

The bishops of the Evangelical Lutheran Church of Finland and most of the priests who worked in the Sámi area knew the Sámi language and considered its use very important. The Evangelical Lutheran Church of Finland also paid the priests more if they were able to serve their parishioners in the Sámi language. However, not all priests were sufficiently proficient in the Sámi language, as this was not an absolute requirement, and

\footnotetext{
32 Lehtola 2012, pp. 135, 284, 297; Nyyssönen 2014, p. 66; Laila Nikunlassi, “Utsjoen kirkonkylänkansakoulu vuosina 1929-1939", in Pigga Keskitalo, Veli-Pekka Lehtola, Merja Paksuniemi (eds.), Saamelaisten kansanopetuksen ja koulunkäynnin historia Suomessa, 179-180. ${ }^{33}$ Suomenmaa 9:2 (WSOY: Porvoo, 1931), 51-57. See also Lehtola 2012, 34, 82-95.
} 
in the harsh conditions of the north, it was also otherwise difficult at times to obtain priests. The Church did not have any official Sámi policy, but the attitude was fundamentally dependent on individuals. In general, however, the Finnish priests of the Sámi area sympathised with the Sámi almost without exception and considered it important to maintain the Sámi language and culture. ${ }^{34}$

The situation of the Skolt Sámi was clearly worse in this sense. The Petsamo Orthodox Congregation included all the Orthodox in the area, the largest group of whom were Russians. In addition to them and the Skolt Sámi, there were also many Karelians in the congregation. The language used in the Orthodox Church, including religious texts, had traditionally been Russian. In Petsamo, this situation did not change between the World Wars, as Russian was the only language understood by members of all three ethnic groups. With regard to religious texts, there was no help from works published in Northern Sámi and later in Inari Sámi. The Skolt Sámi differed from the two so much that the texts were not comprehensible. ${ }^{35}$ They were clearly separate languages, which made the situation of the Sámi people in Finland more difficult when they tried to make their voices heard and promote their interests. As the total number of Sámi was small, their fragmentation into three separate groups made them seem even more insignificant.

\section{Conclusions}

In a society where the majority population constitutes a sizable fraction of the overall population and where their dominance is undeniable, the question of implementing multiculturalism is primarily addressed by how the majority population wishes to organize it. Cultural minorities have the opportunity to make proposals or even demand that their interests be

\footnotetext{
${ }^{34}$ Ibid.; Esko Kähkönen, Katekeetat Suomen Lapissa 200 vuotta (Lapin korkeakoulu: Rovaniemi, 1988), 274-292.

35 Suomenmaa 9:2, 407-408. See also Metropoliitta Leo, "Petsamon ortodoksinen luostari ja seurakunta", in Jouko Vahtola, Samuli Onnela (eds.). Turjanmeren maa. Petsamon historia 1920 1944 (Petsamo-Seura ry: Rovaniemi, 1999), 434-435, 449-450, 453-460.
} 
taken into account, but small minorities are not able to go against the will of the majority. In Finland, ethnic Finns were in absolute dominance over the Sámi. Although the Sámi were a significant local minority in northern Lapland, legal decisions concerning multiculturalism were made at the national level.

The situation of the Sámi was aggravated by their small number, which was further divided into three distinct ethnic groups whose languages differed significantly. The Sámi did not speak as a unified interest group, nor did they have their own political or cultural organisations. However, there seems to have been a fairly unanimous desire among the Sámi elite that the migration of Finns to the Sámi 'home region' should be severely restricted. Similarly, the Sámi should be guaranteed the opportunity to continue their 'traditional way of life' without fear of spreading 'modern age' side effects to the area. Finnish culture was considered a threat, and acculturation was considered undesirable.

However, there was one notable exception to acculturation. Many of the Sámi people seem to have supported bilingualism. Learning the Sámi language at home was considered important, but at the same time, the aim was to ensure that Sámi young people had a sufficiently good command of the official language, i.e. Finnish. It would open equal opportunities for the Sámi in all walks of life. This was also the opinion of the Finnish authorities in charge of the school system. Sámi children and young people therefore attended a Finnish-language school. The exception was mainly the teaching of religion, as it was generally believed that everyone should receive the word of God in their own mother tongue. For that reason, church life in the Sámi area was also organised in both Sámi and Finnish.

The Finns held two sharply different attitudes towards the extent to which multiculturalism could be allowed in Lapland. In northern Finland in particular, there were a relatively large number of highly educated Finns who were in favour of preserving the Sámi language and culture. For them, the Sámi were a minority group that had to be supported in every way in their national goals. These Finns took an active part in the public debate and worked to create an autonomous region for the Sámi. Their ideas also 
received some support in ministries and elsewhere in the state administration.

In the end, however, there were more opponents of multiculturalism than supporters among Finns. Ethnic Finns, especially those living in the Sámi area, were vocally opposed to Sámi autonomy and the granting of any kind of 'privileges' to the Sámi. These Finns felt that supporting the Sámi violated the rights of local Finns.

The Finnish government, parliament and most government agencies also took the view that the Sámi were not given self-government or other support to preserve the Sámi language and culture. It seems that most Finns considered the Sámi to be primitive and inferior, and therefore, they did not consider the Sámi culture worthy of support. They probably did not appreciate any kind of multiculturalism but wanted to develop Finland towards a united, monocultural and monolingual society. In their view, such homogeneity and consensus would have made Finland stronger. In this respect, Finland followed nationalist trends between the World Wars, although Finland's attitude towards the Swedish minority was quite positive when comparing the position of minorities in different European countries in the 1920s and 1930s. 


\title{
References:
}

\author{
A. 1. Unprinted documents \\ Kansallisarkisto [Finnish National Archives]: \\ Kaarlo Hillilän arkisto D:7 \\ Petsamon kihlakunnan kruununvoudin arkisto BI:45.
}

\section{A. 2. Printed documents}

Helsingin Sanomat (newspaper): 1.11.1937.

Rovaniemi (newspaper): 7.2.1925; 3.3.1925; 2.4.1925; 18.2.1926; 11.5.1926;

19.6.1926; 11.5.1929; 3.3.1936; 2.7.1936; 4.7.1936, 7.7.1936; 3.5.1938.

Suomen Asetuskokoelma N:o 101/1921.

Suomen Kuvalehti (magazine): 17/1937.

Suomen Tilastollinen Vuosikirja 1922. Helsinki, 1922.

Suomen Tilastollinen Vuosikirja 1932. Helsinki 1932.

Suomen Tilastollinen Vuosikirja 1942. Helsinki 1943.

Suomenmaa 9:2. WSOY: Porvoo, 1931.

Valtiopäiväasiakirjat 1925, Liitteet IV,2.

Valtiopäiväasiakirjat 1925. Asiakirjat II V.

\section{B. Research literature and articles}

Eagan, Jennifer L. "Multiculturalism”, in

Encyclopedia Britannica, https://www.britannica.com/topic/multiculturalism (7.7.2021).

Kähkönen, Esko. Katekeetat Suomen Lapissa 200 vuotta. Lapin korkeakoulu: Rovaniemi, 1988.

Lehtola, Veli-Pekka. Saamelaiset suomalaiset - kohtaamisia 1896-1953. Helsinki: SKS, 2012.

Metropoliitta Leo. "Petsamon ortodoksinen luostari ja seurakunta”, in Jouko Vahtola, Samuli Onnela (eds.). Turjanmeren maa. Petsamon historia 1920-1944. Petsamo-Seura ry: Rovaniemi, 1999.

Nikunlassi, Laila. “Utsjoen kirkonkylänkansakoulu vuosina 1929-1939”, in Pigga Keskitalo, Veli-Pekka Lehtola, Merja Paksuniemi (eds.), 
28 | Revista Română de Studii Baltice şi Nordice / The Romanian Journal for Baltic and Nordic Studies 13 (1)

Saamelaisten kansanopetuksen ja koulunkäynnin historia Suomessa. Turku: Siirtolaisuusinstituutti, 2014.

Nyyssönen, Jukka. "Saamelaisten kouluolot 1900-luvulla", in Pigga Keskitalo, Veli-Pekka Lehtola, Merja Paksuniemi (eds.), Saamelaisten kansanopetuksen ja koulunkäynnin historia Suomessa. Turku: Siirtolaisuusinstituutti, 2014.

Uola, Mikko. "Kuussaari, Eero". Kansallisbiografia-verkkojulkaisu. Studia Biographica 4.

https://kansallisbiografia.fi/kansallisbiografia/henkilo/7749 (29.12.2020). 